\title{
COMPARISON OF POLLEN MORPHOLOGICAL STRUCTURES OF SOME TAXA BELONGING TO ASPARAGUS L. AND FRITILLARIA L. (LILIACEAE) FROM TURKEY
}

\author{
H. Ozler* And S. Pehlivan ${ }^{1}$ \\ The Ministry of Environment and Forest, Forest Tree Seeds and Tree Breeding \\ Research Directorate, P.O. Box 11, 06560, Ankara-Turkey
}

Key words: Asparagus, Fritillaria, Liliaceae, Pollen morphology

\begin{abstract}
Pollen grains of 20 taxa from two genera of the Liliaceae were examined and compared by LM (light microscope), SEM (scanning electron microscope) and pollens of four taxa were also examined with TEM (transmission electron microscope). Pollen grains shed as monads. They are monosulcate and ellipsoidal. Fritillaria crassifolia subsp. crassifolia Freyn \& Smt. sometimes sheds the pollen as dyads. Exine is semitectate and the tectum is perforate. Columellae are simplicolumellate. Ectexine is thicker than endexine. Exine sculpture (ornamentation) is reticulate, reticulate-rugulate, rugulate and retipilate in Asparagus pollens and reticulate, suprareticulate, rugulate-reticulate and striate-reticulate in Fritillaria pollens. Sulcus extends from distal to proximal in some pollens of Asparagus and Fritillaria.
\end{abstract}

\section{Introduction}

The Liliaceae contains approximately 250 genera and 3500 species. There are approximately 400 Liliaceous species in Turkey and it is one of the richest families. According to recent studies, 49 taxa of Fritillaria and 13 taxa of Asparagus are available in Turkey. The endemism ratio is $36.53 \%$ in Fritillaria and 23\% in Asparagus. These genera have economic and pharmaceutical importance (Davis et al. 1984, 1988, Seçmen et al. 1998, Güvenç 1996, Guner et al. 2000). No detailed palynological studies have been found concerning these genera except for the LM studies by Radulescu (1973) and Schulze (1980, 1982); by Gori (1982), El-Ghazali (1993), Kosenko (1991a, 1991b, 1992, 1999) and SEM and TEM studies. Among monocotyledones plants, the Liliaceae family is a difficult group due to taxonomical and systematic reasons. Some authors explained that the comparative study of pollen morphology of the whole Liliaceae by SEM and TEM hasn't been studied in detail yet (Zavada 1983, Doyle and Hotton 1991, Kosenko 1999a). In order to obtain more morphological data to solve some of these problems, the pollen grains of 20 taxa were comparatively examined in detail for the first time.

\section{Materials and Methods}

The pollen materials were obtained from the Faculty of Pharmacy of Ankara University, the Faculty of Science of Hacettepe University and the Faculty of Arts and Science, Gazi University herbariums. For the light microscopy (LM) investigations, pollen grains of 20 taxa, taken from herbarium materials, were prepared according to the methods of Wodehouse (1935) and Erdtman (1960). Pollen dimensions of all species were measured in such amounts that the resulting data followed Gaussian curves. These measurements are shown in Table1. For scanning electron microscopy (SEM) investigations, the pollen grains were put on stubs, sputter-coated with gold plate and examined under a Jeol JSM-840A scanning electron microscope. For transmission electron microscopy (TEM) studies, acetolyzed pollen grains were stained with $2 \% \mathrm{OsO}_{4}$ and with uranyl acetate, dehydrated and embedded in epon-araldite according to the method described by Skvarla and Turner (1966). Ultrathin sections of the pollen grains were obtained with a glass knife in a

*Author for correspondence; email: hulyaozler@hotmail.com ${ }^{1}$ Department of Biology, Faculty of Arts and Science, Gazi University, 06500, Ankara-Turkey. 
Reichert Supernova microtome. Post staining was performed with lead citrate for 5 minutes (Reynold 1963) and the sections were examined under a Zeiss EM9. The pollen morphological terminologies by Walker (1974 a, b), Faegri and Iversen (1989) and Punt et al. (1994) were used.

Specimens investigated: Asparagus acutifolius L. C3 Antalya: Akseki, Çaltıllçukur-Değirmenler road, 650m, 22.7. 1995; A. Duran 3074 GAZI. A. verticillatus L. A5 Sinop: Boyabat, Ilıca village, gardenside, 4.6.1993, A. Guvenç 18173 AEF. A. officinalis L. B5 Kayseri: Yılanlı mountain, 1200m, 23.5.1993, M. Koyuncu 18232 AEF. A.lycicus P.H. Davis C3 Antalya: Between Elmal1-Korkuteli, out going of Elmal, inside of farm, 1100 m, 11.6.1992, A. Guvenç,16663 AEF. A. coodei P.H. Davis C4 Karaman: Between Mut-Ermenek, $10 \mathrm{~km}$ before Ermenek, Q. cocciferae forest, brushwood side, 1150m, 24.5.1992, A. \& U. Güvenç 16939 AEF. A. lycaonicus P. H. Davis B4 Konya: Cihanbeyli, Boluk lake, 1010m, the back of Alkim factory, salty and with sodium carbonate slopes, 11.7.1992 A. \& U. Guvenç 16654 AEF. A. persicus Baker: B4 Ankara: Polatlı Sazılar village, the side of Porsuk brook, 19.6.1993, A. \& U.Guvenç 18426 AEF. A. palaestinus Baker C5 Mersin: Tarsus Çayboyu village, pass the village after 5km, sandy land 50 m, 19.6.1994 A. \& U. Guvenç 18603 AEF. F. aurea Schott C6 K. Maraş: Goksun-Değirmendere, püren passageway, M. Ekici 1275 GAZI. F. acmopetala subsp. wendelboi Rix C4 Antalya: Gazipaşa, Cimbiti wold, H. Sumbul 1285 AEF. F. whittallii Baker C3 Antalya: Akseki, Guzelsu, Salamut wold, M. Koyuncu 18225 AEF. F. crassifolia subsp. crassifolia Freyn \& Smt. B8: Erzurum: Kapıkaya place, N. Tanker \& K. Baykal 2860 AEF. F. alburyana Rix B9 Erzurum: Hinıs, Bingol Mountain, alpinic steppe, M. Koyuncu et al. 10106 AEF. F. bithynica Baker C2: Muğla: The east of Yılanlı Mountain, A. Guner \& B. Yıldız, 34967 HUB. F. fleisheriana Steudel \& Hochst ex Schultes \& Schultes A3 Ankara: $5 \mathrm{~km}$ before Beypazarı, gypsed steppe, Z. Aytaç et al. 5703 GAZI. F. sibthorpiana (Sm) Baker C2 Muğla: Koyceğiz, Candır village, A. Guner et al. 35031 HUB. F. minima Rix B9 Van: Gevas, Artos Mountain north with stone slopes, M. Koyuncu \& N. Demirkus, 11736 VAN. F. armena Boiss A8 Erzurum: Between Bayburt-Askale, Kop Mountain passageway, alpinic steppe, Ca. 2400m, 13.6.1981 T. Baytop \& R. Çetik, 10049 AEF. F. elwesii Boiss C3 Antalya: Around Alanya, Bademtas village, M. Koyuncu, 19631 AEF.

The symbols AEF, GAZI, HUB and VAN stand for herbarium sheets from the Faculty of Pharmacy of Ankara University, the Faculty of Science and Arts of Gazi University, the Faculty of Science Hacettepe University and the Faculty of Educational Yüzüncü Yıl University, respectively.

\section{Results and Discussion}

General remarks to the genus: Asparagus

Pollen grains of 8 Asparagus species, 3 of which are endemic, are monads monosulcate, ellipsoidal. Exine is semitectate and the tectum is perforate. Exine sculpture is reticulate, reticulate-rugulate, rugulate or retipilate. Sulcus extends from distal to proximal in the examined seven taxa with the exception of $A$. coodei. Sulcus membrane is granulate, rugulate or psilate. Sulcus ends are rounded in all investigated taxa. Sulcus becomes narrow at the equator, widens at the poles. The number of the lumina in $1 \mu \mathrm{m}^{2}$ is $1-12$, the diameter of lumina is approximately $0.10-0.55 \mu \mathrm{m}$, the number of perforation in $1 \mu \mathrm{m}^{2}$ is $2-6$ at the sulcus side or at the lateral surface. The diameter of a perforation is approximately $0.08-0.18 \mu \mathrm{m}$ and the thickness of a murus is on average 0.09-0.25 $\mu \mathrm{m}$. Ectexine is thicker than endexine in TEM micrographs in A. verticillatus and A. lycaonicus. Ectexine is thicker in A. verticillatus than in A. lycaonicus. Endexine is rather thin in both species. Columellae are simplicolumellate (Figs. 1-10, 23-36, 59, 60).

\section{Fritillaria}

Pollen grains of 12 endemic taxa were shed as dyads in F. crassifolia subsp. crassifolia (5\%) and the other species were monosulcate, and ellipsoidal. Exine was semitectate and the tectum was perforate. Exine sculpture was reticulate, suprareticulate, rugulate-reticulate or striate-reticulate. 

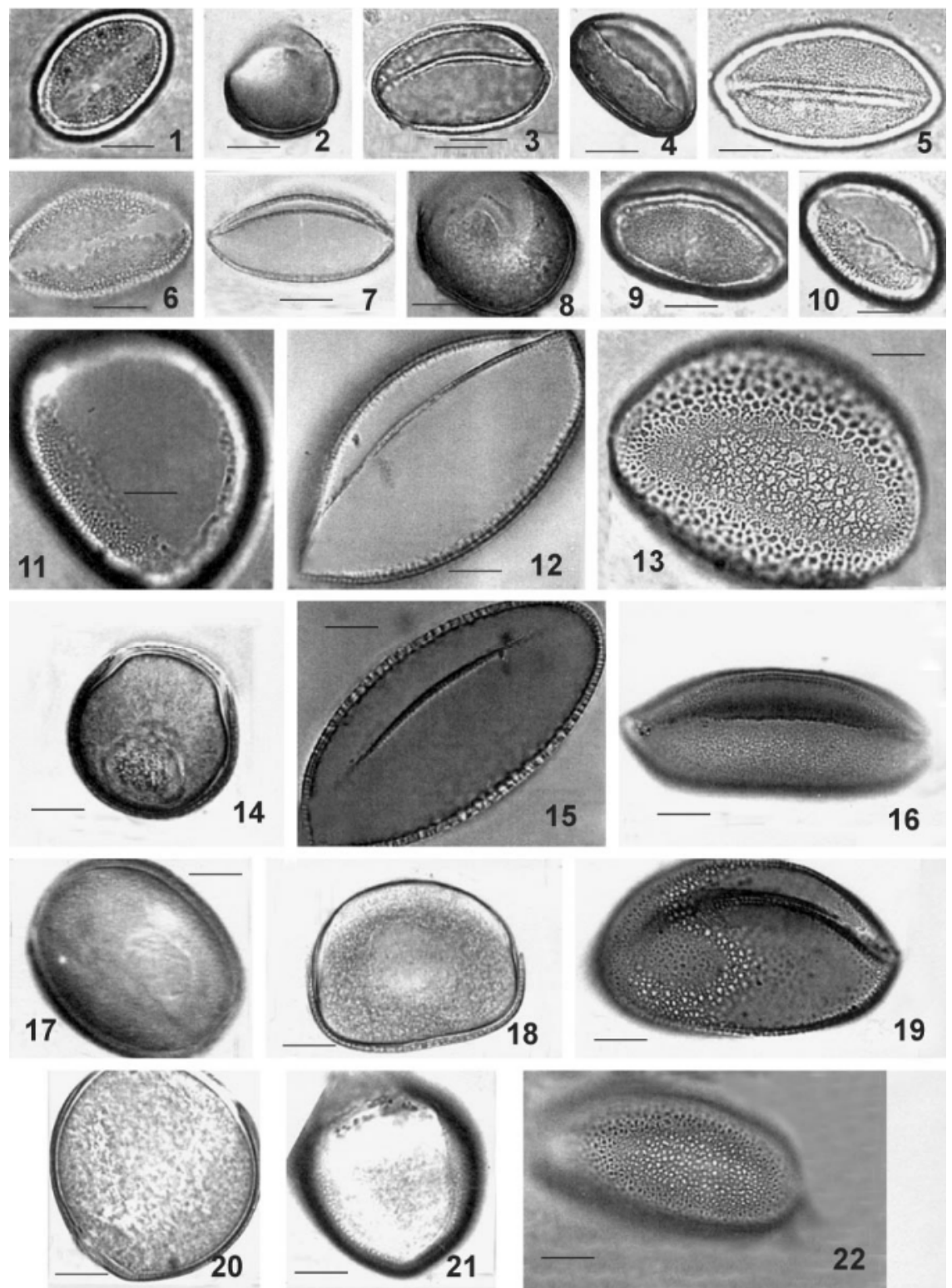

Figs. 1-22: LM microphotographs. 1. Asparagus acutifolius Pollen grain in distal view (E). 2. A. verticillatus Pollen grain in equatorial view in optical section (W). 3. A. officinalis Pollen grain in oblique view (E). 4-5. A. lycicus Pollen grain in oblique view (W) (4). Pollen grain in distal view with ornamentation (E) (5). 6. A. coodei Pollen grain in distal view with ornamentation (E). 7. A. lycaonicus Pollen grain in oblique view (E). 8-9. A. persicus Pollen grain in equatorial view in optical section (W). (8) Pollen grain in oblique view with ornamentation (W) (9). 10. A. palaestinus Pollen grain in distal view (E). 11. Fritillaria aurea Pollen grain in optical section in distal view (E). 12. F. acmopetala subsp. wendelboi Pollen grain in oblique view (E). 13. F.whitallii Ornamentation on proximal side (E). 14. F. michailovskyi Pollen grain in equatorial view (W). 15. F. alburyana Pollen grain in oblique view (E). 16. F. bithynica Pollen grain in oblique view with ornamentation (E). 17. F. crassifolia subsp. crassifolia Pollen grain in distal view (W). 18. F. sibthorpiana Pollen grain in oblique view (W). 19. Fritillaria minima Pollen grain in oblique view with ornamentation (E). 20. F. fleischeriana Pollen grain in equatorial view (W). 21. F. armena Pollen grain in optical section in equatorial view (W). 22. F. elwesii Ornamentation on proximal side (E). $(\mathrm{LM} \times 1000$, Scale $=10 \mu \mathrm{m}$ in all figures); (E: Acetolyzed W: Non acetolyzed pollen grains). 
Sulcus extended from distal to proximal in $F$. aurea, $F$. bithynica and $F$. sibthorpiana. Sulcus membrane is gemmate or granulate. The number of granule in $2 \mu \mathrm{m}^{2}$ on sulcus membrane was approximately 2-9, the number of gemmae in $2 \mu \mathrm{m}^{2}$ was approximately two in $F$. elwesii. Sulcus end were rounded or sharp. At the lateral surface or at the edge of the sulcus the number of lumina in $1 \mu \mathrm{m}^{2}$ was $1-4$, the diameter of lumina was approximately $0.17-0.97 \mu \mathrm{m}$, the number of perforation in $1 \mu \mathrm{m}^{2}$ was 3-7. The diameter of a perforation was approximately $0.12-0.25 \mu \mathrm{m}$ and the thickness of a murus was on an average $0.20-0.74 \mu \mathrm{m}$. In the ultrathin sections of $F$. armena and $F$. whittalli, ectexine was thicker than endexine. Ectexine was thicker in $F$. whittalli than in $F$. armena. Endexine was very thin (Figs. 11-22, 37-58, 61,62).

In this study, a comparative pollen morphological study of 20 entomogamous taxa, 15 of which are endemic, were done using LM, SEM. Four taxa belonging to Asparagus and Fritillaria were also examined with TEM in addition to LM and SEM. The common characteristic of the pollen grains of the investigated taxa is that their pollen apertures are monad monosulcate. It was observed that only a small amount of dyad pollen was found in F. crassifolia subsp. crassifolia. Kosenko (1991a) found that F. eduardii had dyad and tetrad pollens. The predominance of monosulcate aperture in monocotyledons, as in Asparagales and Liliales, is emphasized by Harley and Zavada (2000). Liliaceae and overwhelming majority of Lilialean complex have monosulcate pollens. The evolution of distal sulcate pollen may have occurred in Mezosoic geological periods. Typically, monoaperturate Asparagus and Fritillaria pollens are shed as ellipsoidal monads. Monosulcate aperture may be strong palynological evidence for the common origin of monocotyledon and dicotyledons. Sulcate, colpate, colporate pollen apertures are the most common in biotically pollinated families and sulcate pollen has a much older pollen record than those of both porate and colpate pollen (Kuprianova 1969, 1979, Sporne 1972, Zavada 1983, Linder 2000).

During the present study, some remarkable differences in the measurement of dimensions were observed between taxa. Among the examined genera, the biggest pollen size was found in $F$. sibthorpiana and A. persicus (Table 1). F. armena species studied by Kosenko (1991a), is discussed under $F$. pinardii Boiss in Turkish flora (Davis et al. 1988).

No data about sulcus extention to proximal and sulcus ends have been observed in any work other than those by Schulze (1980), Pehlivan and Ozler (2003) and Guler and Pehlivan (2006). Chanda et al. (1979) explained that extended sulcate type of aperture were not common and that were occasionally found in both dicotyledones and monocotyledones. The sulcus ends are rounded in all investigated Asparagus pollens and in Fritillaria pollen grains except for $F$. aurea and $F$. bithynica (Figs.1-20, 23-58). The longest length of the sulcus (Slg) was seen in $F$. aurea, the shortest was in A. coodei. In comparison to Asparagus, the widest sulcus was measured in Fritillaria pollens (Table 1). Some researchers have shown that the sulcus features may be a taxonomic characteristic in some families (Schulze 1980, 1982, Faegri and Iversen 1989, Kosenko 1991a, 1991b, 1992, 1999, Halbritter and Hesse 1993, Friis et al. 1997).

No other previous studies related to these genera provided data about the sulcus membrane characteristics except for the research on Fritillaria species by Kosenko (1991a, 1992, 1999). According to Kosenko (1991a, 1999) sulcus membrane surface in Fritillaria species were granular or plicate granular and sulcus membrane surface were good characteristics for classification of Fritillaria and its subspecies. It was found that sulcus membrane is gemmate in F. elwesii and granulate in other Fritillaria species pollens. Sulcus membrane of Asparagus pollen grains are granulate and psilate. The edges of the sulcus are irregular in investigated taxa (Table 1, Figs.1-21, 23-58).

Semitectate, tectum perforate exine and thin exine in the examined taxa are primitive characteristics in monocotyledones and are observed in the early stages of angiosperm evolution (Radulescu 1973, Schulze 1980, 1982, El-Ghazali 1993, Kosenko 1991a, 1991b, 1999, Furness 

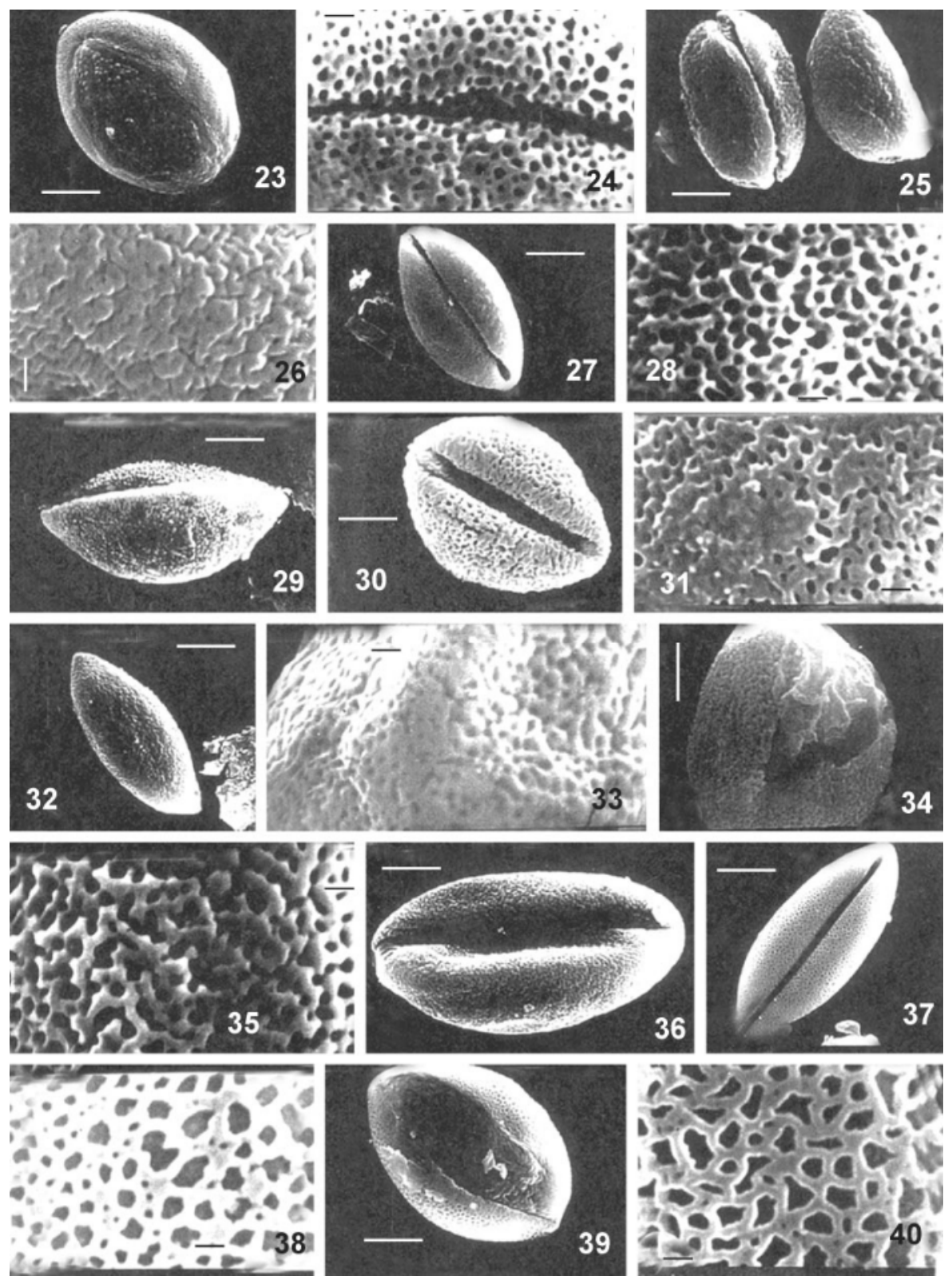

Figs. 23-40 SEM microphotographs. 23-24. Asparagus acutifolius $(\times 1800)$. Pollen grain in distal view with granulate sulcus membrane (23). Reticulate ornamentation on sulcus side $(\times 10000)(24) .25-26$. A. verticillatus Pollen grain in distal view on the left and in oblique view on the right $(\times 3000)(25)$. Rugulate ornamentation $(\times 10000)(26)$. 27-28. A. officinalis $(\times 2200)$ Pollen grain in distal view (27). Reticulate-rugulate ornamentation $(\times 10000)(28)$. 29. A. lycicus Pollen grain in distal view with reticulate-rugulate ornamentation $(\times 3000)$. 30-31. A. coodei Pollen grain in distal view $(\times 3000)(30)$. Reticulate-rugulate ornamentation $(\times 9000)(31) .32-33$. A. palaestinus Pollen grain in proximal view $(\times 2000)(32)$. Reticulate-rugulate ornamentation $(\times 10000)(33)$. 34-35. A. lycaonicus Pollen grain in equatorial view with granulate sulcus membrane $(\times 5000)$ (34). Retipilate ornamentation $(\times 15000)$ (35). 36. A. persicus Pollen grain in distal view with rugulate ornamentation $(\times 3500)$. 37. Fritillaria aurea Pollen grain in distal view $(\times 1300)$. 38. Fritillaria aurea with suprareticulate ornamentation $(\times 8000)$. 3940. F. acmopetala subsp. wendelboi Pollen grain in distal view with granulate sulcus membrane $(\times 1800)(39)$. Suprareticulate ornamentation $(\times 8000)(40)$. (Scale $=10 \mu \mathrm{m}$ Figs. 23, 25, 27, 29, 30, 32, 34, 36, 37, 39 and rest $1 \mu \mathrm{m})$. 

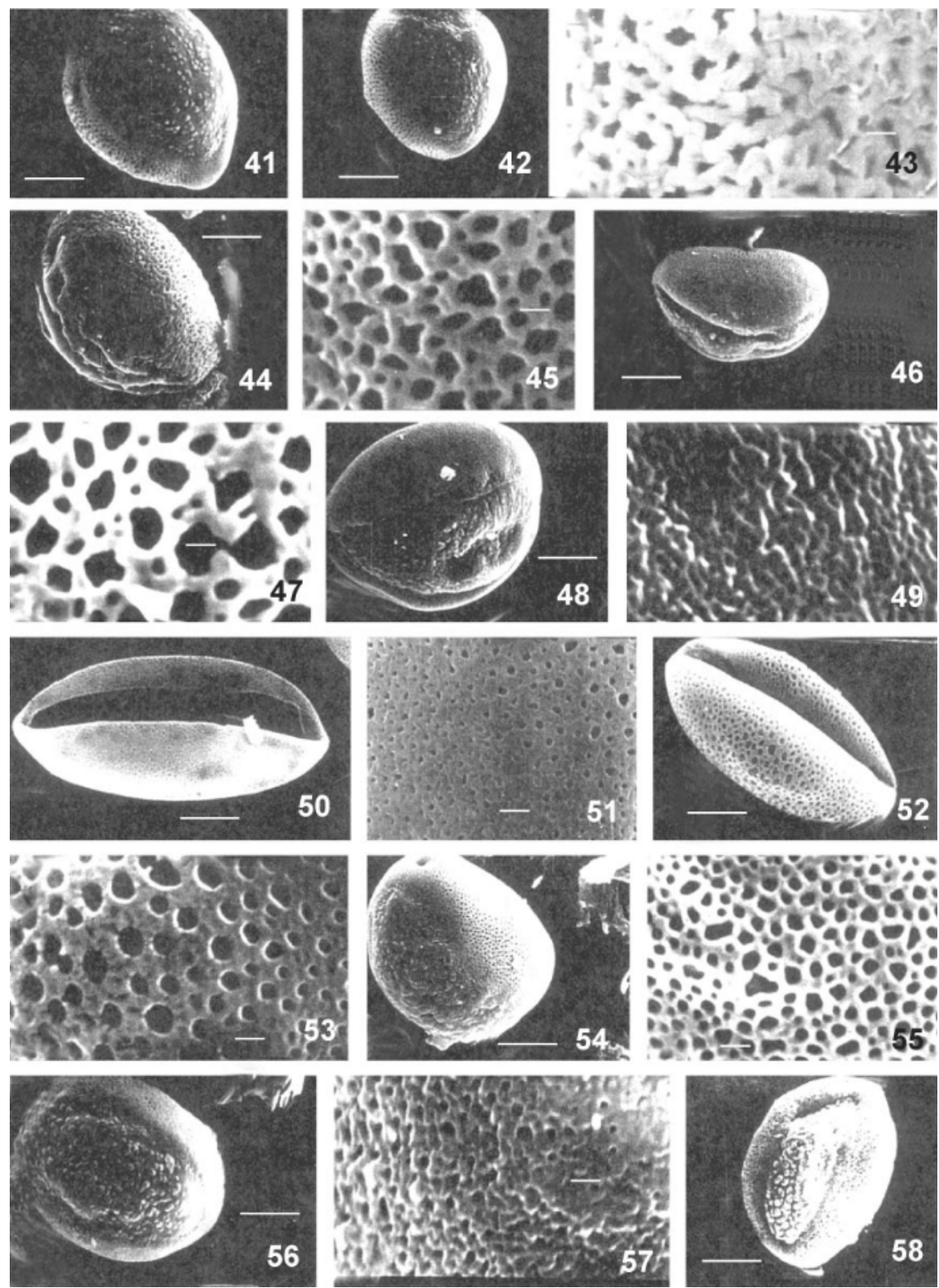

Figs. 41-58 SEM microphotographs. 41. F. whitallii pollen grain in distal view with granulate sulcus membrane $(\times 1800)$. 42-43. F. crassifolia subsp. crassifolia Pollen grain in distal view with granulate sulcus membrane $(\times 1500)(42)$. Reticulate ornamentation $(\times 10000)(43) .44-45$. F. michailovskyi Pollen grain in distal view $(\times 1600)(44)$. Suprareticulate ornamentation $(\times 9500)(45) .46-47$. F. alburyana Pollen grain in distal view with granulate sulcus membrane $(\times 1500)(46)$. Reticulate ornamentation $(\times 10000)(47) .48-49 . F$. bithynica Pollen grain in distal view with granulate sulcus membrane $(\times 2000)(48)$. Rugulate-reticulate ornamentation $(\times 10000)(49)$. 50-51. F. fleischeriana Pollen grain in distal view $(\times 2000)(50)$. Striatereticulate ornamentation $(\times 5500)(51) .52-53$. F . sibthorpiana Pollen grain in distal view $(\times 1500)(52)$. suprareticulate ornamentation $(\times 6000)(53)$. 54-55. Fritillaria minima Pollen grain in distal view with granulate sulcus membrane $(\times 1800)$ (54). Reticulate ornamentation $(\times 8500)(55)$. 56-57. F. armena Pollen grain in distal view with granulate sulcus membrane $(\times$ 2000) (56). Rugulate-reticulate ornamentation $(\times 10000)(57)$. 58. F. elwesii Pollen grain in distal view with gemmate sulcus membrane $(\times 1500)$. (Scale $=10 \mu \mathrm{m}$ Figs. 41, 42, 44, 46, 48, 50, 52, 54, 56, 58 and rest $1 \mu \mathrm{m})$. 
Table 1. Pollen morphological parameters of Asparagus and Fritillaria taxa.

\begin{tabular}{|c|c|c|c|c|c|c|c|c|c|}
\hline Taxon & $\begin{array}{c}\mathrm{A} \\
\mu \mathrm{m}\end{array}$ & $\begin{array}{c}\text { B } \\
\mu \mathrm{m}\end{array}$ & $\begin{array}{l}\mathrm{A} / \mathrm{B} \\
\mu \mathrm{m}\end{array}$ & $\begin{array}{l}\text { Slg } \\
\mu \mathrm{m}\end{array}$ & $\begin{array}{l}\text { Slt } \\
\mu \mathrm{m}\end{array}$ & $\begin{array}{c}\text { Exine } \\
\mu \mathrm{m}\end{array}$ & Intine & Orn & SMO \\
\hline A. acutifolius (W) & $25.29 \pm 1.83$ & $18.98 \pm 1.27$ & 1.33 & $29.46 \pm 2.16$ & $5.28 \pm 1.89$ & $1.02 \pm 0.13$ & $0.81 \pm 0.47$ & $\mathrm{R}$ & G \\
\hline A. acutifolius (E) & $27.93 \pm 2.0$ & $17.25 \pm 2.11$ & 1.61 & $31.15 \pm 2.47$ & $3.96 \pm 1.17$ & $1.57 \pm 0.22$ & & & \\
\hline A. verticillatus (W) & $20.91 \pm 0.95$ & $17.28 \pm 1.20$ & 1.21 & $26.72 \pm 3.01$ & $6.38 \pm 1.04$ & $1.07 \pm 0.18$ & $0.94 \pm 0.20$ & $\mathrm{Rg}$ & $\mathrm{Rg}$ \\
\hline A. verticillatus $(\mathrm{E})$ & $22.87 \pm 1.46$ & $18.15 \pm 1.93$ & 1.26 & $27.70 \pm 3.39$ & $7.68 \pm 1.85$ & $1.39 \pm 0.30$ & & & \\
\hline A. officinalis (W) & $27.16 \pm 1.62$ & $19.74 \pm 1.21$ & 1.37 & $32.37 \pm 2.93$ & $6.33 \pm 1.68$ & $1.18 \pm 0.32$ & $0.84 \pm 0.17$ & $\mathrm{R}-\mathrm{Rg}$ & $\mathrm{Rg}$ \\
\hline A. officinalis (E) & $31.37 \pm 2.91$ & $22.28 \pm 2.05$ & 1.40 & $35.70 \pm 2.99$ & $5.44 \pm 1.90$ & $1.74 \pm 0.22$ & & & \\
\hline A. lycicus (W) & $27.28 \pm 2.90$ & $19.22 \pm 2.85$ & 1.41 & $34.76 \pm 3.29$ & $6.33 \pm 1.68$ & $1.18 \pm 0.32$ & $0.84 \pm 0.17$ & R-Rg & $\mathrm{Rg}$ \\
\hline A. lycicus (E) & $37.92 \pm 3.56$ & $21.91 \pm 2.81$ & 1.73 & $43.20 \pm 4.30$ & $5.44 \pm 1.90$ & $1.74 \pm 0.22$ & & & \\
\hline A. coodei $(\mathrm{W})$ & $25.40 \pm 2.52$ & $17.79 \pm 2.40$ & 1.42 & $21.36 \pm 2.90$ & $5.48 \pm 2.04$ & $1.00 \pm 0.14$ & $0.83 \pm 0.09$ & $\mathrm{R}-\mathrm{Rg}$ & $\mathrm{Rg}$ \\
\hline A. coodei (E) & $31.08 \pm 2.01$ & $24.45 \pm 1.47$ & 1.27 & $26.37 \pm 3.50$ & $8.83 \pm 2.31$ & $1.65 \pm 0.22$ & & & \\
\hline A. lycaonicus (W) & $24.42 \pm 1.51$ & $16.40 \pm 1.18$ & 1.48 & $29.34 \pm 1.97$ & $5.04 \pm 0.87$ & $1.00 \pm 0.17$ & $0.81 \pm 0.16$ & Rt & G \\
\hline A. lycaonicus $(\mathrm{E})$ & $0.66 \pm 2.33$ & $19.57 \pm 3.95$ & 1.56 & $35.46 \pm 2.99$ & $5.09 \pm 1.87$ & $1.50 \pm 0.31$ & & & \\
\hline A. persicus $(\mathrm{W})$ & $30.80 \pm 1.66$ & $21.76 \pm 1.43$ & 1.41 & $35.32 \pm 3.16$ & $8.28 \pm 2.17$ & $1.17 \pm 0.30$ & $0.78 \pm 0.13$ & $\mathrm{Rg}$ & G \\
\hline A.persicus $(\mathrm{E})$ & $38.91 \pm 3.27$ & $22.72 \pm 3.17$ & 1.71 & $44.80 \pm 4.16$ & $6.03 \pm 2.12$ & $1.78 \pm 0.22$ & & & \\
\hline A. palaestinus $(\mathrm{W})$ & $28.97 \pm 4.43$ & $20.01 \pm 1.43$ & 1.27 & $32.57 \pm 2.37$ & $5.30 \pm 1.42$ & $0.99 \pm 0.17$ & $0.76 \pm 0.19$ & R-Rg & $\mathrm{P}$ \\
\hline A. palaestinus (E) & $36.51 \pm 3.51$ & $24.42 \pm 1.47$ & 1.49 & $41.72 \pm 3.23$ & $4.45 \pm 1.26$ & $1.79 \pm 0.22$ & & & \\
\hline F. aurea $(\mathrm{W})$ & $48.03 \pm 2.58$ & $35.27 \pm 2.91$ & 1.36 & $55.95 \pm 3.49$ & $16.48 \pm 5.22$ & $1.68 \pm 0.38$ & $0.81 \pm 0.31$ & $\mathrm{R}$ & G \\
\hline F. aurea (E) & $60.27 \pm 3.06$ & $41.22 \pm 4.26$ & 1.46 & $66.91 \pm 3.36$ & $20.73 \pm 4.47$ & $2.16 \pm 0.37$ & & & \\
\hline \multicolumn{10}{|l|}{ F. acmopetala } \\
\hline \multicolumn{10}{|l|}{ F. acmopetala } \\
\hline subsp. wendelboi $(\mathrm{E})$ & $54.95 \pm 4.53$ & $40.15 \pm 3.21$ & 1.36 & $48.00 \pm 3.67$ & $14.80 \pm 4.72$ & $2.08 \pm 0.33$ & & & \\
\hline F. whittallii $(\mathrm{W})$ & $45.07 \pm 2.81$ & $34.71 \pm 3.08$ & 1.29 & $40.32 \pm 3.28$ & $21.34 \pm 3.44$ & $1.62 \pm 0.31$ & $0.81 \pm 0.18$ & $\mathrm{R}$ & G \\
\hline F. whittallii (E) & $54.30 \pm 2.45$ & $42.84 \pm 2.03$ & 1.26 & $49.82 \pm 4.53$ & $22.01 \pm 4.89$ & $2.00 \pm 0.20$ & & & \\
\hline \multicolumn{10}{|l|}{ F. crassifolia } \\
\hline $\begin{array}{l}\text { subsp. crassifolia }(\mathrm{W}) \\
\text { F. crassifolia }\end{array}$ & $44.73 \pm 2.5$ & $33.24 \pm 1.79$ & 1.34 & $39.16 \pm 3.22$ & $13.06 \pm 2.17$ & $1.90 \pm 0.26$ & $0.79 \pm 0.26$ & $\mathrm{R}$ & G \\
\hline subsp. crassifolia (E) & $55.32 \pm 3.10$ & $37.04 \pm 3.80$ & 1.49 & $48.68 \pm 3.43$ & $12.26 \pm 5.13$ & $1.89 \pm 0.14$ & & & \\
\hline F. michailovskyi (W) & $45.15 \pm 1.68$ & $36.12 \pm 1.22$ & 1.25 & $40.76 \pm 1.63$ & $23.47 \pm 2.24$ & $1.99 \pm 0.30$ & $1.25 \pm 0.44$ & $\mathrm{R}$ & G \\
\hline F. michailovskyi (E) & $58.67 \pm 3.89$ & $41.67 \pm 2.06$ & 1.40 & $49.01 \pm 5.66$ & $16.72 \pm 5.51$ & $2.04 \pm 0.19$ & & & \\
\hline F.alburyana $(\mathrm{W})$ & $49.68 \pm 2.25$ & $35.68 \pm 1.79$ & 1.39 & $43.63 \pm 3.05$ & $16.05 \pm 4.08$ & $2.10 \pm 0.28$ & $0.93 \pm 0.23$ & $\mathrm{R}$ & G \\
\hline F. alburyana $(\mathrm{E})$ & $60.45 \pm 2.17$ & $42.79 \pm 3.11$ & 1.41 & $49.92 \pm 3.51$ & $13.99 \pm 3.91$ & $2.01 \pm 0.78$ & & & \\
\hline F. bithynica $(\mathrm{W})$ & $43.22 \pm 2.67$ & $32.72 \pm 3.71$ & 1.32 & $47.52 \pm 4.61$ & $17.87 \pm 4.68$ & $1.96 \pm 0.17$ & $0.90 \pm 0.16$ & Rg-R & G \\
\hline F. bithynica $(\mathrm{E})$ & $49.17 \pm 8.31$ & $34.98 \pm 3.95$ & 1.40 & $49.44 \pm 4.21$ & $15.00 \pm 3.76$ & $1.90 \pm 0.20$ & & & \\
\hline F. fleisheriana (W) & $49.60 \pm 3.41$ & $35.41 \pm 5.22$ & 1.40 & $44.66 \pm 4.24$ & $15.00 \pm 5.18$ & $1.77 \pm 0.17$ & $0.86 \pm 0.25$ & St-R & G \\
\hline F. fleisheriana (E) & $58.89 \pm 4.77$ & $42.76 \pm 3.65$ & 1.37 & $35.20 \pm 3.65$ & $18.52 \pm 5.74$ & $1.90 \pm 0.01$ & & & \\
\hline F. sibthorpiana $(\mathrm{W})$ & $43.76 \pm 2.27$ & $30.68 \pm 2.82$ & 1.42 & $47.96 \pm 2.40$ & $12.24 \pm 3.76$ & $1.84 \pm 0.29$ & $0.84 \pm 0.09$ & SR & $\mathrm{G}$ \\
\hline F. sibthorpiana $(\mathrm{E})$ & $66.81 \pm 2.98$ & $36.17 \pm 2.90$ & 1.84 & $70.40 \pm 3.71$ & $11.04 \pm 3.10$ & $1.92 \pm 0.15$ & & & \\
\hline F. minima $(\mathrm{W})$ & $46.27 \pm 1.43$ & $37.48 \pm 1.91$ & 1.23 & $41.14 \pm 1.87$ & $23.76 \pm 2.22$ & $1.85 \pm 0.23$ & $1.07 \pm 0.27$ & $\mathrm{R}$ & G \\
\hline F. minima $(\mathrm{E})$ & $59.43 \pm 3.08$ & $40.98 \pm 1.83$ & 1.45 & $46.13 \pm 4.27$ & $14.19 \pm 3.26$ & $1.93 \pm 0.10$ & & & \\
\hline F.armena (W) & $46.27 \pm 2.40$ & $33.74 \pm 1.38$ & 1.37 & $41.11 \pm 2.64$ & $15.36 \pm 4.97$ & $1.90 \pm 0.15$ & $0.88 \pm 0.18$ & $\mathrm{R}$ & $\mathrm{G}$ \\
\hline F. armena $(\mathrm{E})$ & $48.55 \pm 4.36$ & $36.20 \pm 3.07$ & 1.34 & $42.86 \pm 4.19$ & $13.30 \pm 3.09$ & $1.88 \pm 0.06$ & & & \\
\hline F. elwesii (W) & $42.75 \pm 1.83$ & $33.60 \pm 1.66$ & 1.27 & $38.29 \pm 2.47$ & $18.53 \pm 4.56$ & $1.85 \pm 0.27$ & $0.84 \pm 0.23$ & Rg-R & $\mathrm{Gm}$ \\
\hline F. elwesii (E) & $54.82 \pm 3.81$ & $37.44 \pm 3.19$ & 1.46 & $49.16 \pm 3.32$ & $11.52 \pm 4.07$ & $1.92 \pm 0.08$ & & & \\
\hline
\end{tabular}

A: Long axis of pollen grains, B: Short axis of pollen grains, Slg: Length of the sulcus, Slt: Width of the sulcus, (W): Non acetolyzed pollen grains (LM), (E): Acetolyzed pollen grains (LM), Orn (Ornamentation): Sculpture of pollen wall, SMO: Sulcus membrane ornamentation R: Reticulate, Rg: Rugulate, SR: Suprareticulate, St : Striate, Rt: Retipilate, G: Granulate, Gm: Gemmate

and Rudall 2000, Simpson 1983, 1985, 1987, Takahashi 1987, Zavada 1983, 1984, Walker 1974 a, 1974 b, Crane 1989, Hughes and Audrey 1994, Pehlivan and Ozler 2003, Guler and Pehlivan 2006).

As a result of TEM examinations, we also observed that endexine is very thin in all examined taxa (Figs. 59-62). Ectexine is thicker in Fritillaria pollen grain in comparison to 
Asparagus pollen grains. While endexine is very thin and uninterrupted in A. verticillatus it is interrupted in A. palaestinus, $F$. whitallii and $F$. armena. The perforation number is observed to be the greatest in A. lycicus and in $F$. armena. In the investigated taxa, exine sculpture is reticulate, reticulate-rugulate, striate-reticulate, retipilate and suprareticulate (Figs. 23-58). ElGhazali (1993) explained that Asparagus flagellaris pollen had psilate exine sculpture. However, we haven't observed such an exine sculpture in Asparagus pollens. Reticulate, microreticulate, macroreticulate, faveolate-plicate, and tuberculate exine structure were mentioned in previous studies of Fritillaria pollen grains (Radulescu 1973, Schulze 1980, Kosenko 1991a, 1999). In this study it is detected that reticula are rather big in Fritillaria pollens in comparison with the Asparagus taxa (Figs.23-36). According to Kosenko (1991a, 1992) small reticulae are more plesiomorphic characteristics than big ones. Kosenko (1991a) and Radulescu (1973) had grouped Fritilaria pollen grains according to the density of reticula. Schulze (1982) found out that the diameter of the lumina was under $1 \mu \mathrm{m}$ or approximately $2 \mu \mathrm{m}$ in Asparagus. During the present study it was found that the diameter of lumina was $0.10-0.55 \mu \mathrm{m}$ in Asparagus pollens. Schulze $(1980,1982)$ stated that the diameter of reticula were $1-4 \mu \mathrm{m}$ in Fritillaria. In the present study, it was observed that the diameter of lumina is approximately $0.17-0.97 \mu \mathrm{m}$ in Fritillaria pollens.
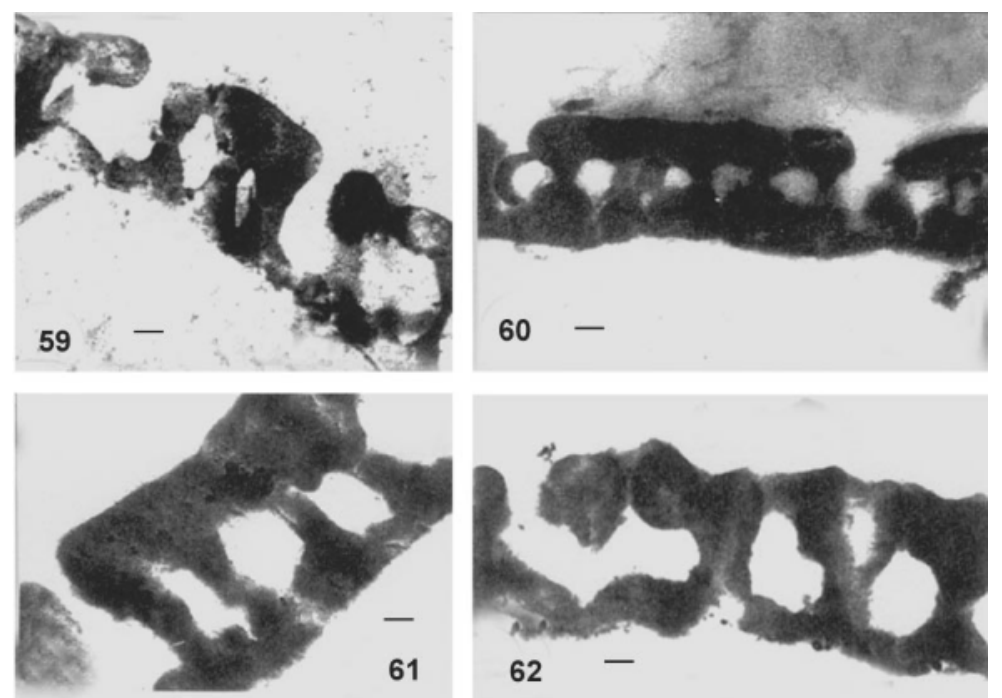

Figs. 59-62. TEM microphotographs of exine structure (× 30000). 59. A. verticillatus, 60. A. palaestinus. 61. F.whitallii, 62. F. armena. Scale $=0.23 \mu \mathrm{m}$.

Ornamentational characteristics of pollen grains of the investigated taxa as observed in SEM micrographs have been used for their diagnostic features and accordingly both Asparagus and Fritillaria are proposed to be divided into four types as shown below:

\section{Index}

Asparagus

Type I: Ornamentation is reticulate: A. acutifolius

Type II: Ornamentation is rugulate: A. verticillatus and A. persicus.

Type III: Ornamentation is retipilate: A. lycaonicus

Type IV: Ornamentation is reticulate-rugulate: A. officinalis, A. lycicus, A. coodei, and A. palaestinus 
Fritillaria:

Type I: Ornamentation is suprareticulate: F. sibthorpiana, F. aurea, F. acmopetala subsp. wendelboi and F. michailovskyi.

Type II: Ornamentation is reticulate: $F$. whittallii, $F$. crassifolia subsp. crassifolia, $F$. alburyana, F.minima and $F$. elwessii.

Type III: Ornamentation is rugulate-reticulate: $F$. bithynica and $F$. armena.

Type IV: Ornamentation is striate-reticulate: $F$. flesheriana.

\section{Acknowledgements}

The authors thank the collectors for allowing them to use their specimens.

\section{References}

Chanda, S., K. Gosh and S. Nillson. 1979. On the polarity and tetrad arrangement in some mono and diapertürate angiosperm pollen grains. Grana 18: 21-31.

Crane, P.R. 1989. Paleobotanical evidence on the early radiation of nonmagnoliid dicotyledones. Pl. Syst. Evol. 162: 165-191.

Davis, P.H., R.R. Mill and K. Tan, K. 1984. Flora of Turkey and the East Eagean Islands. Univ. Press, Edinburg.

Davis, P.H., Mill, R.R. and K. Tan (Eds.). 1988. Flora of Turkey and the East Eagean Islands (Suppl.). Univ. Press, Edinburg.

Doyle, J.A. and C.L. Hotton. 1991. Diversification of early angiosperm pollen in cladistic context. In: Pollen and Spores. Edited by Blackmore, S. and Barnes, S.H. (Ed) Clarendon Press-Oxford, The systematics Association Special Volume 44: 169-195.

El-Ghazali, G.E.B. 1993. A study on the pollen flora of Sudan. Rev. of Paleo. Palyn. 76: 99-345.

Erdtman, G. 1960. The acetolysis method. A revised description. Sven. Bot. Tidskr. 54: 561-564.

Faegri, K. and J. Iversen. 1989. Textbook of pollen analysis. Faegri, K .,Kalland, P.E. and Knzywinski, K J. (Eds.), Wiley \& Sons., New York, Toronto, Singapore.

Furness, C.A. and P.J. Rudall. 2000. Aperture absence in pollen of monocotyledons. In: Pollen and Spores: Morphology and Biology: 249-257. Harley, M.M., Morton, C..M. and Blackmore, S. (Eds). Royal Botanic Gardens, Kew.

Friis, E.M., P.R. Crane and K.R. Pedersen. 1997. Anacostia a new basal angiosperm from the early Cretaceous of North America and Portugal with trichotomo-colpate/monocolpate pollen. Grana 36: 225-244.

Gori, P. 1982. An ultrastructural investigation of microspores, pollen grains and tapetum in Asparagus officinalis. Phytomorphology 32: 277-284.

Guler, U. and S. Pehlivan. 2006. Pollen morphology of some species belonging to Codonoprasum and Allium sections of Allium (Liliaceae-Alliaceae) genus. Biologia, Bratislava 61: 449-455.

Guner, A., N. Ozhatay, T. Ekim and Canbaser, K.H. 2000. Flora of Turkey and the east Eagean Islands (Suppl. 2). Univ. Press, Edinburg.

Güvenç, A. 1996. Türkiye'de Yetişen Asparagus (Kuşkonmaz) Türleri Üzerinde Farmasötik Botanik Yönünden Araştırmalar. A.Ü. Sağlık Bilimleri Enstitisü, Ankara.

Halbritter, H. and M. Hesse. 1993. Sulcus morphology in some monocot families. Grana 32: 87-99.

Harley, M.M. and M.S. Zavada. 2000. Pollen of the monocotyledons: selecting characters for cladistic analysis. In: Monocots: Systematics and Evolution. Wilson, K.L. and Morrison, D.A. (Eds), CSIRO, Melbourne..

Hughes, N.F. and B. Audrey. 1994. Search for antecedents of early creataceous monosulcate columellate pollen. Rev. of Paleo. and Palyn. 83: 175-183.

Kosenko, V.N. 1991a. Pollen morphology of the family Liliaceae Bot. Zh.(Leningrad) 76: 1201-1210.

Kosenko, V.N. 1991b. Pollen morphology of the genus Fritillaria (Liliaceae). Bot. Zh. (Leningrad) 76: 16961706. 
Kosenko V.N. 1992. Pollen morphology and systematic problems of the Liliaceae family. Bot. Zh. (Leningrad) 77: $1-15$

Kosenko, V.N. 1999. Contributions to the pollen morphology and taxonomy of the Liliaceae. Grana 38: 20-30.

Kuprianova, L.A. 1969. On the evolutionary levels in the morphology of the pollen grains and spores. Pollen et Spores 11: 333- 351.

Kuprianova, L.A. 1979. On the possibility of the development of tricolpate pollen from monosulcate. Grana 18: $1-4$.

Linder, H.P. 2000. Pollen morphology and wind pollination in angiosperms. In: Pollen and Spores: Morphology and Biology, Harley, M.M., Morton, C.M. and Blackmore, S. (Eds), Royal Botanic Gardens, Kew.

Pehlivan, S. and H. Ozler. 2003. Pollen morphology of some species of Muscari Miller (LiliaceaeHyacinthaceae) from Turkey. Flora 198: 1-11.

Punt, W., S. Blackmore, S. Nilsson and A. Le Thomas. 1994. Glossary of pollen and spore terminology. LPP Foundation, Uttecht.LPP Contributions Series No 1.

Radulescu, D. 1973. Recherches morpho-palynologiques sur la famille Liliaceae. Acta Botanica Horti Buc. 193- 248.

Reynold, E.S. 1963. The use of lead citrate at high $\mathrm{pH}$ as on electron opaque stain in electron microscopy. Stain Technol. 43: 139-144.

Rudall, P.J., Ca. Furness, M.V. Chase and M.F. Fay. 1997. Microsporogenesis and pollen sulcus type in Asparagales (Lilianae). Can. J. Bot.75: 408-430.

Schulze, W. 1980. Beiträge zur taxonomie der Liliifloren VI. Der umfang der Liliaceae.Wiss. Z.F.Schiller Univ. Jena, Math.- Nat. R. 29: 607-636

Schulze, W. 1982. Beiträge zur taxonomie der Liliifloren x. Asparagaceae. Wiss. Z.F. Schiller Univ. Jena, Math.- Nat. R. 31: 309-330.

Seçmen, O., Y. Gemici and G. Gork, L. Bekât, and E. Leblebici .1998. Tohumlu Bitkiler Sistematiği. Ege Üniversitesi Basımevi, Bornova, zmir.

Simpson, M.G. 1983. Pollen ultrastructure of the Haemodoraceae and its taxonomic significance. Grana 22: 79-103.

Simpson, M.G. 1985. Pollen ultrastructure of the Tecophilaceae. Grana 24: 77-82.

Simpson, M.G. 1987. Pollen ultrastructure of the Pontederiaceae. Grana 26: 113-126.

Skvarla, J.J. and B.L. Turner. 1966. Systematic implications from electron microscopic studies of Compositae pollen. A Rev. Ann. Mo. Bot. Gard. 53: 220-256.

Sporne, K.N. 1972. Some observations on the evolution of pollen types in dicotyledons. New Phytol. 71:181-185.

Takahaschi, M. 1987. Development of omniaperturate pollen in Trillium komtschaticum (Liliaceae). Amer. J. Bot. 74: 1842-1852.

Walker, J.W. 1974a. Evolution of exine structure in the pollen of primitive angiosperms. Amer. J.Bot. 61: 891-902.

Walker, J.W. 1974b. Aperture evolution in the pollen of primitive angiosperms. Amer. J. Bot. 61: 1112-1136.

Wodehouse, R.P. 1935. Pollen grains. MacGraw Hill, New York.

Zavada , M.S. 1983. Comparative morphology of monocot pollen and evolutionary trends of apertures and wall structures. Bot. Rev. 49: 331-378.

Zavada, M.S. 1984. Angiosperm origins and evolution based on dispersed fossil pollen ultrastructure. Ann. Miss. Bot. Gard. 71: 444-463. 